\section{Towards a Reduction of Grammar Teaching a Lexical Analysis}

\section{Priyono}

FKIP Universitas Mataram

\begin{abstract}
Learning a language is essentially learning vocabulary, and it is the lexical competence that enables the learners to use the language with ease. It will be argued that such an ability includes, among the important ones, the knowledge of semantic properties and syntactic behavior of the lexical item as well as its collocation. The acquisition of the semantic properties of a lexical item is necessaary to support the learner's ability to distinguish different senses encoded in the lexical item, and the knowledge of syntactic behavior reflects the learner's ability to recognize and produce the syntactic variants into which a lexical item can enter. The collocational competence is the knowledge of the lexical behavior in particular that enables the learner to envisage the possible cooccurrence of other words with the given lexical item. Thus, the acquisition of lexical competence would cover a large part of syntax. This understanding of the nature and characteristics of lexicon would raise some questions on the relevance of putting great emphasis on the teaching of grammar only.
\end{abstract}

Key words: Lexical competence/knowledge, semantic property, syntactic property, collocation.

Vocabulary is a central element in language learning. From the learner's point of view, knowledge of vocabulary is more dependable than knowledge of grammar. Widdowson (1978) has claimed that native speakers can better understand ungrammatical utterances with accurate vocabulary than those with accurate grammar and inaccurate vocabulary. This is in line with Wilkins (1972) in saying: "without grammar very little can be conveyed, without vocabulary, nothing can be conveyed." A similar proposition is put forward by Krashen! that "When students travel, they don't carry grammar books, they carry dictionaries." More substantial statements in support of vocabulary is given in the preface of Clark (1993):

Words are the starting point. Without words, children can't talk about people, places, or things, about actions, relations, or states. Without words, children have no grammatical rules. Without words, there would be no sound structure, and no syntax. The lexicon, then, is central in language acquisition.

Ironically, this imporant element of language has long been neglected in the studies of language and language teaching. Researches in language have been dominated by the studies of syntax, phonology, and discourse (see Richards, 1976; Candlin, $1988^{2}$ : Long and Richards, $1997^{3}$ ). The same is true with the teaching of English as a second language.

The formal instruction of English as a foreign language in Indonesia has implicitly recognized vocabulary as an essential part of the instruction. In the current English curriculum for secondary school (1994), the mastery of vocabulary is measured as the standard of completion of the program. However, vocabulary teaching has never been a priority in the English classroom. Earlier in 1990, the Department of Education and Culture reported that $54.1 \%$ of English teachers in Indonesia were in favour of teaching grammar, and only $7.3 \%$ of vocabulary. Currently when the communicative approach has been introduced through PKG program, the shift of orientation has been from grammar not to vocabulary, but to language functions. The vocabulary remains controversially marginal.

It is quite unfortunate that while the current English curriculum for secondary schools puts reading as first priority above listening, spéaking, and writing, very little attention is paid to the teaching of vocabulary. Recent studies in second language vocabulary acquisition demonstrate a strong reciprocal relation between vocabulary and reading comprehension. Laufer (1997), for example, claims that insufficient vocabulary does hinder comprehension regardless of the strategies the reader employs. She suggests further that clues will not be available from texts unless a minimum of $95 \%$ text coverage is known to the readers. Support to this claim is given by Coady (1997) who concluded that highly frequent words are needed to help beginners develop their vocabulary and be independent readers. Only with this vocabulary threshold are learners able to read effectively, guess the meaning from clues available in the text, understand the messages, and learn more new words. 
It will be argued throughout this article that the acquisition of lexicon would enable the learners to use the language without difficulties since what constitutes lexical knowledge is knowing the words with their properties and how their syntactic behavior. Among these important aspects to be taken into serious considerations are the semantic and collocational behavior of the word and (for the verb) the argument structures.

Lexis is therefore an essential part of learning a language, which should be incorporated into the learning materials no matter what approach is being employed. There has been evidence that a large part of English grammar is lexically related. Studies in second language acquisition such as those by Ard and Gass (1987), and Yip (1994) have indicated that difficulties experienced by ESL learners which appeared to be grammatical are essentially lexical.

In this article, the nature and behavior of the English verb will be examined to account for the phenomena. The evidence is derived from the lexical analysis of the English verb lexicon since the verb plays a central role in syntax. No clause is ever found without a verbal element, and it will be evident in the following how a verb shapes its syntactic configuration.

\section{THE VERB ARGUMENT STRUCTURE}

In English as in many other languages, verbs are an important lexical category. Verbs enter into relations that shape the syntactic configuration. These configurations can be described by means of arguments assigned by the verb grammatical function: Predicate. The function operates within the system known as Lexical Rules which assumes that each verb inherits two lexical representations: a lexical semantic representation and a lexical syntactic representation (Levin and Hovav, 1995; Pinker, 1996). Levin and Hovav elaborate further that the former encodes the syntactically relevant aspects of verb meaning, and the latter the argument-taking properties of a verb. In Lexical semantic literature, the semantic representation is sometimes referred to as lexical conceptual structure and the syntactic representation known as argument structure.

The notion of lexical conceptual structure may refer to the so-called argument structure (cf. Bresnan, 1982; Selkirk, 1982; Pinker, 1989; Grimshaw, 1990;
Pustejovsky, 1991; Fisher, 1994, among others) in that the meaning of the verb specifies the number of participants (arguments) involved and the roles played in the eventuality denoted by the verb. In a more specific terminology, the verb's argument can be labeled in terms of thematic roles such as "Agent" and "Theme". For example, the verb put as in She put the dictionary on the table, can be described as having three arguments, namely Agent (she), Theme (the dictionary), and Location (on the table). However, for a more practical reason, the concept can be simplified. Instead of using the thematic roles, Pinker (1989) has differentiated the verb's arguments in terms of Subject, Object, Second Object, and Prepositional Object. With this disticntion, the argument structure of the verbs below can be described as follows:

She put the dictionary on the table.

[Subj, Obj, Prep Obj]

Tim has given me the money.

[Subj, Obj, Sec Obj]

Bill ate the bread.

[Subj, Obj]

With these argument-taking properties, the three verbs are different respectively in their lexical representation. The verb eat, for instance, cannot dativize as the verb give. Thus, *Bill ate me the bread is grammatically unaccceptable. On the other hand, the verb give cannot leave either its direct object or beneficiary. Both *Tim has given me and *Tim has given the money are ungrammatical. Likewise, put never leaves the prepositional object as the goal. As is apparent, the object and the goal (Location) for the verb put, and the direct object and the beneficiary for give are obligatory. Violation to this principle would result in ungrammaticality.

The argument-taking property also specifies whether a verb must take an object or appear without it in a sentence while some verbs can be in both categories. The verbs hit, contain, put, etc always require a noun phrase object to appear in a sentence, while the verbs disappear, happen, come, etc never take any. These two categories are known as Pure Transitive and Pure Intransitive (cf. Kilby, 1984). By contrast, there are verbs which can take and leave an obejct. Included in this category are the verbs eat, read, write, etc. These are all illustrated in the following:

1a. He never hit the ball very far. 
*b. He never hit.

2a. He came early this morning.

*b. He came someone early in the morning.

3a. She is writing a novel.

b. She is writing

Sentences 1 and 2 demonstrate that the noun phrase object is obligatory for the verbs such as hit, and such an object must be absent for come. But sentences $3 \mathrm{a}$ and $b$ indicate that the noun phrase object is optional in the surface structure for the verb write. These examples demonstrate that the built-in properties of the verbs determine the types of syntactic structures they can shape. The properties of a verb then distinguish from others so that some verbs can enter into particular constructions, but some cannot. In this case, differnt properties assign different syntactic behavior. This will be discussed further under the section Syntactic Property.

\section{SEMANTIC PROPERTY}

There is a common perception in second language learner's experience that learning words is the main part of learning the language (cf. Little, 1994). And the important aspect of learning words is to know its meaning. Experience as an ESL learner shows that meaning of a word is the first lexical property to be given priority. This is quite obvious from the learner's dependence on dictionaries rather than grammar books when working with the language (cf. Krashen, 1989; Little, 1994). The reliance on vocabulary could be due to the realibility of the content words for a survival communnication.

Since a word often has more than one meaning, it is necessary for a learner to be able to identify and distinguish an intended meaning from others. Some words have a number of senses which all relate to the same origin. In a dictionary, these extended senses are listed under a single entry. This is the case of polysemy. On the contrary, there are words with multiple meanings and the same form or sound, but not related to the same origin. This is the case of homonymy. To some extent, this sounds like the meaning of multiple-sense word can be predicted from its original meaning. However, the problem with polysemous words is that the extension of word meaning varies (see Pustejovsky, 1998). The matter may get even worse when interlexical factors interferes. There is often lexical gap between two different languages. Consider the following sentences with load.

1. . her heart sank under a fearful load of guilt (2).

2...with a load on his wagon (21)

3. . to load up some wool on a wagon (27)

4. . to load our trailer with wood (47)

5 ... if the van did not load the food (52)

6. Despite his heavy work load .....(71).

These six sentences convey six different senses of the word load, but all relate to the original meaning, that is, to remove something from one place to another or container. Among these different senses, three of them are nouns and others verbs. A free tranlsation into Bahasa Indonesia would yield the following expressions.

1. hatinya terasa berat dibebani perasaan bersalah

2. dengan muatan di kendaraannya

3. mengisi kendaraan penuh dengan wol

4. memuati trailer kita dengan kayu

5. kalau kendaraannya tidak memuat makanan

6. walaupun beban kerjanya berat

Looking at the Indonesian versions, there are at least three different English words that could be the paraphrases of the word load. In sentence 1, it is equal to burden, in 3 to fill up, in 6 burden. For Indonesian learners of English, sense number 1 may not readily be apparent. And the trace of meaning of load in sentences 4 and 5 can be misleading. In sentence 4 , trailer is the object while in 5 , the "trailer" (wagon) is the subject of the verb load. This shift of function encodes a different sense. In Bahasa Indonesia, the two senses are represented by the following lexical items (memuati and memuat).

The problem with the homonymous words is that the word has the same form and sound, but the meaning cannot easily be traced from the original. These words are potentially ambiguous as illustrated in the following sentences.

$7 \mathrm{a}$. They stopped by the bank of the river.

b. The State bank employs more people compared to the other banks.

8 a. We took a rest after such a long hard work.

b. Please take some more job, and we'll do the rest. 
The word bank in $7 \mathrm{a}$ is completely different from $7 \mathrm{~b}$, and its meaning is not related or derived from either one. The same is true with the word rest in sentence 8. There seems to be no trace for guessing the meaning from the origin of in the word.

\section{SYNTACTIC PROPERTY}

The built-in property inherent in a lexical item as in the verb argument structure enables the verb to enter into a relation that shape syntactic configuration. In this case the meaning of the verb determines the syntactic structures. Throughout this section it will be evident that only some verbs can enter into a resctricted range of syntactic constructions. Let us now have a look at the syntactic variants that only a number of verbs can produce.

\section{BENEFACTIVE AND DATIVE VARIANTS}

Dative is a very common variant of the double-object construction in English and some other languages (see Chung, 1976; Levin, 1985:32). The alternation to Dative variant is characterized by the permutation of a direct object with an indirect object. Included in this group of verbs are give, tell, sell, send, show, owe, write, etc. The examples below will demonstrate that some verbs dativize and some do not.

1a. Jane gave the poster to Anne.

b. Jane gave Anne the poster.

2a. Jane told the bad news to me.

b. Jane told me the bad news.

3a. They owe an apology to me.

b. They owe me an apology.

These are the verbs among others that participate in dative alternation, but the following verbs cannot enter into it.

4a. Phil returned the books to the library.

b. *Phil returned the library the books. 5a. They constructed a house for me.

b. *They constructed me a house.

The general principle that could be derived from the evidence is that partici pating verbs in Dative alternation are those with the arguments Subject, Object and Beneficiary. Sentences 1-3 display these argument structures. But there is a problem with the verbs return and construct. These two verbs encode the same arguments as the verbs give, tell, owe, and so on, and they sit well in the Benefactive variant. As evident from 4 and 5 , however, these verbs cannot dativize.

\section{CAUSATIVE AND INCHOATIVE VARIANTS}

The English causative verb is the main feature in transitivity alternations. In the area of lexical semantics, studies have been conducted to investigate the syntactic behavior of the causative verb (Smith, 1970; Cruse, 1972; Levin, 1985; Atkins et al, 1986; Levin and Hovav, 1994, 1995). The meaning of the transitive variant is generally described as "cause to V-intransitive" (Levin and Hovav, 1994). The following sentences illustrate the causative behavior. Sentence $6 \mathrm{~b}$ is the paraphrase of 6 a while $c$ is the inchoative variant.

$6 \mathrm{a}$. The boy broke the window.

b. The boy caused the window to break.

c. The window broke.

It is important to note here that, although sentence 6 a entails $c$, there are more principled differences between the two. First, the change of role involving the argument-taking properties of break points out that the object of $6 a$ is the same referent with the subject of $6 \mathrm{c}$. In $6 \mathrm{a}$ the causation (who does the breaking) is specified but in $6 \mathrm{c}$ is not. Therefore, sentence $6 \mathrm{a}$ is agentive while $\mathrm{c}$ is non-agentive. Agentivity in fact plays an important role in causative verb alternations. In relation to the paraphrasing of causative variants as in sentences $6 a$ and $b$, Cruse (1972), referring to the first sentence as the "covert" causative construction and the second as the "overt" causative, has used agentivity as a point of reference to explain the differences between the two. Cruse (1972:520-1) has the following examples:

7a. John galloped the horse around the field 
b. John caused the horse to gallop around the field.

8a. John marched the prisoners.

b. John caused the prisoners to march.

Sentences $7 \mathrm{a}$ and $8 \mathrm{a}$ are covert causative where the objects are agentive. The agentivity allows both sentences to have overt causatives ( $7 \mathrm{~b}$ and $8 \mathrm{~b}$ ). In addition, animacy of object and subject that correlates with the agentive role is also an important factor in covert and overt alternation. This is illustrated in the following sentences taken from Cruse (1972:521).

9 a. $*$ The floods marched the army further north.

b. The floods caused the army to march further north.

10a. *John flew the spark.

b. John caused the spark to fly.

The absence of agentive role in the subject of sentence 9 , and the object of sentence 10 makes only overt causative possible.

The verbs participating in this alternation include boil, break, burn, close, $d r y$, melt, open, sink, etc.

\section{OBJECT-DELETED VARIANT}

Quite a few verbs participate in the transitive and intransitive alternation involving the deletion of object. Among others are the verbs read, bite, cook, draw, drive, eat, write, etc. This group of verbs is similar to causative verbs in that they take both transitive and intransitive variants, but they are different in the relation between the subject/

b. Jim and his neighbour know each other.

c. *Jim and his neighbour know.

In sentences 15a, b, and c, Paul, and Mary can be either Agent or Target in the same event of meeting. Therefore, they may conflate to form a subject. It is evident from the four instances (15-18) that a plural or double subject is indispensable for reciprocal sense. Sentences $15 \mathrm{~d}, 16 \mathrm{~d}$, and $17 \mathrm{c}$ demonstrate that singular subject does not express reciprocity. Although $16 \mathrm{~d}$ is a possible intransitive variant meaning "Bill is a single talker", without the participation of another, the reciprocal sense is not conveyed. Therefore $16 \mathrm{~d}$ is ill-formed.
The lexical semantic analysis of meet (15) and collide (17) would reveal that these verbs are different from talk and know and that the difference is reflected in the syntactic structure. The reciprocal alternation allows intransitive use of meet and collide to appear without the reciprocal marker (each other). The meanings of 15 and 17 are not affected in the absence of the reciprocal marker, because Paul and Mary met, and The car and the truck collided have already implied reciprocity (Dixon's inherently reciprocal). The reciprocal marker would just mean intensification of the meaning of the verbs. This semantic property is found in either talk or know. The absence of reciprocal marker in sentence $16 \mathrm{c}$ results in ambiguity. Meanwhile the verb know in sentence $18 \mathrm{c}$ does not even imply any reciprocal sense at all. Since reciprocal marker is indispensable for the verb know to express reciprocity, sentence $18 \mathrm{c}$ would only mean other than reciprocal.

\section{REFLEXIVE VARIANT}

The preceding section has shown that there is a problem with the intransitive use of the verbs talk and know because they are not inherently reciprocal. A similar problem seems to appear with reflexive alternation. The participating verbs in this alternation are dress, bathe, shave, strip, comb, etc. Some of these are illustrated in the following sentences.

19a. She dressed her son.

b. Her son dressed himself.

c. She dressed herself immediately.

d. She dressed immediately.

20a. The little boy hid himself under the table.

b. The little boy hid under the table.

21a. John hurt himself

b. *John hurt.

22a. He hates himself.

b. *He hates.

The evidence derived from sentence 19 shows the syntactic properties of the verb dress. First, the verb can be either transitive (a, b, c) or intransitive (d). Second, the transitive dress has both reflexive ( $b$ and $c$ ) and non-reflexive variant (a). Third, the reflexive variant allows the reflexive pronoun to be deleted. It turns out 
that the intransitive dress of $19 \mathrm{~d}$ is unaffected by the omission of the pronoun in which case the meaning of the sentence remains reflexive (cf. Atkins, et al, 1986:134; and Dixon, 1991:59). The verb hide is like dress, where the intransitive use cannot be interpreted other than reflexive. Sentence $20 \mathrm{~b}$ means "the little boy hid himself." It is the verbs like dress and hide that are inherently reflexive, and can omit the reflexive pronoun without changing the meaning. This is not the case with hurt and hate (21-22). In both instances the reflexivity of hurt and hate can only be expressed by a reflexive pronoun following the verb. Sentences $21 \mathrm{~b}$ and $22 \mathrm{~b}$ are therefore unacceptable. There is another possible interpretation that $21 \mathrm{~b}$ is derived from the causative somebody hurt John making John hurt an inchoative variant. In this case, the reflexive sense is not implied. The verb hate, on the other hand, has a much stronger sense of being transitive. It is in fact a pure transitive (cf. Kilby, 1984) so that participation in the transitivity or object-deletion alternations is not possible. Hate requires an object to express the meaning. Accordingly the reflexive pronoun is indispensable.

\section{Collocational Competence}

Collocation refers to the co-occurrence of a word and another word or more in the near vicinity. The co-occurrence forms a combination bound in semantic and/or syntactic relation. The collocational combination is relatively free compared to that of the idiomatic expression which is fixed and whose meaning is not predictable from its component. Thus, student diary, boiling water, give away are all examples of collocational combination. The important features of collocational combination are that the meaning of the phrase is apparent from its component. Student diary is a diary for student, boiling water is water which is boiling and so on. There is also a certain degree of substitutability for either the Node or the Collocate. As in student diary, the possible combinations are student organization, studcut bookstore, etc. By contrast, the idiomatic combination does not have these properties. The welknown example kick the bucket shows well the difference: The maning of this idiom (die) is not at all derived from the words kick and bucket, and the construction is quite fixed. Subtituting the bucket with the ball to form kick the ball would change the latter to collocational instead of idiomatic combination. The meaning of its components kick and ball reflects the meaning of this expression.
In collocational combination, the co-occurring word(s) (the Collocate) is restricted by the meaning of the key word (the Node). In this case, the Node selects only a certain words to collocate. The word earn, for example, may collocate with the words and form the following phrasal verbs.

$$
\begin{aligned}
& \text { earn a living } \\
& \text { earn much money } \\
& \text { earn } \$ 70,000 \text { a year }
\end{aligned}
$$

earn respect

This word, however, is not likely to co-occur with the word letter as in receive a letter, which means that the noun letter is not selected to be in the range of the co-occurring words with the verb earn.

The selectional restriction in collocational combination is a potential source of difficulties for some ESL learners. This will be made worse when first language interference takes place. Let us have a look at the corpus citations of the verb earn. The ten most frequent words that co-occur with that verb are living, money, $\$ 50,000$ (including other currency), keep, respect, income, bread, interest, rate, salary/wages as illustrated in the following sentences

I will earn my own living (\#11)

They were convinced they could earn more money (\#33)

I earn $\$ 30,000$ a year, my wife earns $\$ 7000$ a year ( $\# 108$ )

How can I earn my keep on a croft and .... (\#258)

We'll earn the respect of everyone (\#60)

...he did earn any income from the farm (\#154)

I hold that is the duty of every citizen to enable men to earn bread and... (\#290)

This money can be used by businesses to earn interest (\#197)

We are now going to earn a better rate on our money ...(\#150)

Susan Ryan will earn a similar salary when she.... (\#77)

Among these words, some maybe more readily accepted and understood but others may not. In my non-native speaker's judgement, the words living, money, income, salary, $\$ 7000$, are more easily understood than the words keep, respect, and bread to collocate with earn. It is likely that ESL learners would have the same problem. Unless exposed extensively to this input, they might hesitate to comprehend the meaning and be reluctant to use it. Out of the ten words, there is even a 
greater range of "unexpected"' words to collocate with earn. This includes position, mention, kick, punishment, condemnation, etc. This is illustrated in the following sentences:

Her strong exam performane should earn her a university position .... (\#195)

he did enough to earn a mention in.... (\#102)

They made their opponents earn every kick (\#134)

Evil-doers earn their punishment (\#7)

.a continuation of this attitude will earn international condemnation (\#78)

With these collocates, the word earn is even harder to comprehend and may look like a different word.

\section{CONCLUSION}

The description of the lexical properties of the English verbs has demonstrated the complexity of the verb conceptual structure. It also indicates that a large part of grammar is lexically constrained. We have seen that some syntactic structures can only be filled up by a certain number of verbs which share the same properties. The meaning of the verb determines the number of arguments involved in the eventuality denoted by the verb. The verb also restricts other lexical items that are acceptably included in the range of cooccuring words. With this lexical conceptual structure, we cannot expect to have any verbs to enter into a particular syntactic construction. Thus grammatical problems caused can be addressed to this lexical issue. There is principle governing the syntactic behavior of the verb. Verbs which share the same components of meaning tend to have similar syntactic behavior. Therefore, it is possible to group verbs with similar properties into one class that can be characterized, for example, from their syntactic behavior. The characterization of the principled lexical behavior would in turn enable learners to reduce the grammar load and learn the language through the words and their properties.

The knowledge of the lexical properties and behavior constitute the speaker's lexical competence. It has been implied in the description that knowing a word should cover the meaning and its extended senses, syntactic representation, and collocational behavior (it does not mean to exclude its sound and form). The acquisition of the word with these properties would include aspects of grammar and meaning. Of course, it does not mean to exclude discourse which is at the other level not dealt with in this paper.

Note

1 Professor Stephen Krashen made the statement in British Council Confer ence, Milan 1987, and it is quoted on the preceding page under Words of Wisdom in Lewis' Lexical Approach (1993:iii)

2 In the Preface of Carter and McCarthy (1988), Vocabulary and Language Teaching. Longman,

3 In the Preface of Coady and Huckin (1997), Second Language Vocabulary Acquisition. Cambridge University Press.

\section{REFERENCES}

Ard, J. and S. Gass. 1987. Lexical Constraints on Syntactic Acquisition. Studies in Second Language Acquisition 9 (2):233-52. Cambridge: University Press.

Atkins, B.T., J, Kegl, and B. Levin. 1986. Explicit and Implicit Information in Dictionaries. Lexicon Project Working Papers 12. Center for Cogn. Sc. MIT. Cambridge, Massachusetts.

Bresnan, J. 1982. The Mental Representation of Grammatical Relations. Massachusetts: The MIT Press.

Carter, R. and M. McCarthy. 1988. Vocabulary and Language Teaching. London: Longman Group UK Limited.

Chung, S. 1976. An Object-Creating Rule in Bahasa Indonesia. Linguistic Inquiry. v.7, 4187.

Clark, E. V. 1993. The Lexicon in Acquisition. Cambridge: Cambridge University Press.

Coady, J. and T. Huckin. 1997. Second Language Vocabulary Acquisition. Cambridge: Cambridge University Press.

Cruse, D. 1986. Lexical Semantics. Cambridge: Cambridge University Press.

Departemen Pendidikan dan Kebudayaan 1994. Kurikulum 1994, Garis-garis Besar Program Pengajaran. Sekolah Menengah Umum Mata Pelajaran: Bahasa Inggris. 1994. Jakarta: Departemen Pendidikan dan Kebudayaan.

Departemen Pendidikan dan Kebudayaan 1990. Survai Pengajaran Bahasa Inggris di SMP dan SMA Seluruh Indonesia. Laporan Akhir.

Dixon, R.M.W. 1991. A New Approach to English Grammar on Semantic Principles. Oxford: Clarendon Press, 
102 TEFLIN Journal, Volume X Number 1, August 1999

Fisher, C. 1994. Structure and Meaning in the Verb Lexicon: Input for a Syntax-aided Verb Learning Procedure. Language and Cognitive Process. 1994, 9 (4) 473-517. Lawrence Erlbaum Associates Ltd.

Grimshaw, J. 1990. Argument Structure. The MIT Press. Cambridge, Massachusetts.

Kilby, D. 1984. Descriptive Syntax and the English Verb. Croom Helm Ltd.

Krashen, S.D. 1989. We Acquire Vocabulary and Spelling by Reading: Additional Evidence for the Input Hypothesis. The Modern Language Journal. 73(4): 440-64.

Larsen-Freeman, D. 1986. Techniques and Principles in Language Teaching. Oxford University Press.

Laufer, B. 1997. The Lexical Plight in Second Language Reading: Words youdon't know, Words you think you know, and Words you can't guess. In J. Coady and T. Huckin (eds), 1997. Second Language Vocabulary Acquisition. Cambridge: Cambridge University Press.

Levin, B. 1985. Lexical Semantics in Review. Lexicon Project Working Papers. n. 1. Center for Cognitive Science. Cambridge, Massachusetts, The MIT Press.

Levin, B. 1993. English Verb Classes and Alternations. Chicago: The University of Chicago Press.

Levin, B. and M.R. Hovav. 1995. Unaccusativity. MIT Press. Cambridge, Massachusetts,

Little, D. 1994. Words and their Properties: Arguments for a Lexical Approach to Pedagogical Grammar In Terence Odlin (ed.), Perspectives on Pedagogical Grammar. New Yrok: Cambridge University Press.

Pinker, S. 1989. Learnability and Cognition. The Acquisition of Argument Structure. Cambridge, Massachusetts: The MIT Press. .

Pinker, S. 1996. Language Learnability and Language Development. Cambridge, Massachusetts: Harvard University Press.

Pustejovsky, J. 1991. The Generative Lexicon. Computational Linguistics, vol. 17, n.4: 409-41.

Pustejovsky, J. 1998. The Generative Lexicon. Cambridge,Massachusetts: The MIT Press. Richards, J. 1976. The Role of Vocabulary Teaching. TESOL Quarterly, 10(1),77-89.

Selkirk, E. 1982. The Syntax of Words. Cambridge, Massachusetts: MIT Press.

Smith, C.S. 1970. Jespersen's Move and Change Class and Causative Verbs in English. In M.A. Jazayery, E.C. Polome, and W, Winter(eds), Descriptive Linguistics. Linguistic and Literary Studies in honour of Archibald A. Hill. v.2, 101-9.

Widdowson, H.G. 1978. Teaching Language as Communication. Oxford: Oxford University Press.

Wilkins. D. 1972. Linguistics in Language Teaching. Edward Arnold.

Yip. V. 1994. Grammatical Consciousness-raising and Learnability. In Terence Odlin (ed.), Perspective on Pedagogical Grammar. Cambridge: Cambridge University Press. 